\title{
Analysis of the Accessibility of Prague in Czechia in the 1918 - 2020 Period
}

\author{
Tomáš Hudeček
}

The article deals with accessibility development in Czechia since the setting up of Czechoslovakia in 1918 till the year of planned completion of the main motorways and train corridors in 2020 . One hundred years is a sufficiently long period to understand many of geographical processes related to accessibility patterns.

The main goal is to digitalize transport networks for every ten years (dates of Census) and build accessibility models with average speeds, times for changing between trains and waiting times on stations, etc.

The project is also focused on calculating the accessibility of Prague making isochrone maps and deals with a thematic cartography method - radial anamorphosis - as an ideal method for visualization of isochrone surfaces. The results will show the exact time period from which road transportation overtook trains in time accessibility or vice versa. Even though accessibility is investigated in relation to the capital of the Czech Republic, the methodology could be used for any other place in the country.

Key words: accessibility, transport, GIS, Prag, historical development

\section{Analiza dostupnosti Praga u Republici Češkoj od 1918. do 2020.}

Rad se bavi razvojem prometne dostupnosti u Češkoj Republici od osnutka Čehoslovačke do planiranog završetka glavnih cestovnih i željezničkih koridora 2020. Stotinu godina dovoljno je dugo razdoblje kako bi se moglo razumjeti geografske procese povezane s obrascima dostupnosti.

Glavni je cilj rada digitalizacija prometnih mreža za svako međupopisno razdoblje (deset godina) i stvaranje modela dostupnosti s prosječnom brzinom, vremenom presjedanja, vremenom čekanja na stanicama itd.

U radu se također nastoji dati precizan izračun dostupnosti Praga pomoću karata s izokronama te se primjenjuje metoda tematske kartografije - radijana anamorfoza - kao idealna metoda vizualizacije izokronih površina. Rezultati će pokazati točna razdoblja u kojima je cestovni transport brži od željezničkoga i obrnuto. Iako je istraživanje dostupnosti u ovom radu usmjereno na glavni grad Češke Republike, upotrijebljeni model može se primijeniti na bilo koje naselje u državi.

Ključne riječi: prometna dostupnost, transport, GIS, Prag, povijesni pregled 


\section{INTRODUCTION}

Since the middle of last century, accessibility has been carefully studied, not only in geography. Accessibility can be defined as the ease of reaching a certain point in a certain space (Giuliano, 1995). It can also be understood as the potential possibilities of interaction in a space (Rietveld and Bruinsma, 1998).

Accessibility is closely related to mobility. It is linked to the increase in citizens' mobility, i.e. the development of means of transport, higher quality of transport infrastructure and its density. The higher the mobility of citizens, the better the accessibility (of both citizens and places). Nevertheless, in some cases the link to mobility does not prove the same causality. In the last century, Tolley and Turton (1967) pointed out that it was true that people commuted over longer distances, but that was due to the fact that they had to. At that time, higher mobility led to e.g. more extensive decentralisation of services. This means that mobility increased but accessibility did not. For some disadvantaged groups of citizens (e.g. persons without a car) accessibility even worsened. Moreover, various groups of citizens can put emphasis on different aspects related to the price of transport. For example, the factor of price is more important for groups that use public transport than for groups that use individual transport (e.g. Golias, 2002; Nutley, 2003; Spiekermann and Wegener, 1996).

Further use of accessibility analyses is broad because the results can serve e.g. for regional development analyses (e.g. Gutiérrez et al., 1996; Sić, 2008; Li and Shum, 2001), analyses of interaction and contacts between centres (e.g. Spence and Linneker, 1994) and more. Nowadays, studying accessibility is related mostly to geo-informatics and is based on detailed and accurate databases. While theoretical accessibility improves with the development of better-quality infrastructure, real accessibility depends on many other factors; in the case of road transport it can be, for example, traffic density or transport network permeability. A high-quality database poses the main prerequisite for high-quality research of accessibility.

In Czechia, research of time accessibility in a certain area via rail transport dates back to the beginning of the 20th century (e.g. Nový, 1904). Even though these cases consist mainly of cartographically processed temporal distances on the Czech territory, this map - an isochronic map with extensive descriptions in the form of a book - can be considered an initial study in this area.

An important achievement of Czech geography was the use of accessibility studies in order to divide the territory into regions. This was based on the creation of transport divisions for both public and individual transport, inspired by periods of low transport intensity (e.g. Hůrský, 1971, 1978). This catchment rate of regions, i.e. the creation of socalled accessibility regions, was further developed in several studies (Kubeš and Slezáková 2000; Rölc, 2004; Hudeček, 2008).

Apart from studies of connectivity, i.e. the interlinks between significant transport junctions in Czechia (e.g. Grégr. 1994; Mirvald, 1998; Marada, 2003), the most frequent focus in the study of Czech geographic accessibility is placed on the accessibility of major centres of settlement, i.e. the capital city or the regional centres (e.g. Kraft, 2008; Hudeček, 
2010). Attention is also given to geo-informatics studies on software calculations (e.g. Peňáz, 2005).

Currently, the Faculty of Science of the Charles University in Prague is conducting unique historical geographical research called "Analysis of accessibility patterns in Czechia from 1921 to 2020", supported by the Grant Agency of the Czech Republic. The aim of this paper is to describe partial tasks and results of the completed sections of the research.

\section{PAPER AND RESEARCH OBJECTIVES}

The paper was created as part of the GAČR grant"Analysis of accessibility patterns in Czechia from 1921 to 2020". The aim of the research is to perform a complex assessment of accessibility in Czechia over one hundred years. It also intends to point out periods that were favourable to the use of different transport modes in the main settlement centres in Czechia. No similar assessment has been made for the territory of the Czech Republic. The reasons for this are the lack of digital data (which had to be created for the purpose of the research) and the extensive character of the task that requires several years to be completed.

The main objective of this paper is to use isochronic maps to analyse the accessibility of Prague via rail and road transport and to model the changes in accessibility from the period of the establishment of Czechoslovakia, or rather the first Census in 1918, to the planned completion of the main motorways and railway corridors in 2020 . Three periods were determined to ensure sufficient representation of the development for each transport mode. The following years were selected as temporal milestones:

a) 1920, the origin of Czechoslovakia and the whole analysed period;

b) 1960 , the road network before the construction of motorways and high-speed roads; in 1957 the majority of planned railways were completed and electrification was launched;

c) 2020 , the planned completion of the whole motorway and railway network.

Due to the improvement in means of transport and the construction of new infrastructure, we can expect a significant improvement of transport accessibility in the majority of the territory. Therefore, we set out several logical working hypotheses, e.g. time accessibility of Prague decreases over the years, territories with the biggest changes in time accessibility are situated close to newly built motorways or railway corridors. Partial objectives of this part of the research included digitisation of road and rail network in approximately ten-year periods and elaboration of methodology for the creation of accessibility models (e.g. Hudeček, 2008; Blahník, 2008; Kufner, 2010).

\section{DIGITISATION OF MAPS AND AN ACCESSIBLITY MODEL - ROAD}

The condition and extension of the road network were studied throughout the whole 20th century. Old maps were digitised in 10-year intervals (1920, 1930, etc.) which correspond to the years of Census in Czechia. The maps were obtained from various 
institutions. For example, the Czech Office for Surveying, Mapping and Cadastre, the Military Office for Geography and Hydrometeorology in Dobruška, and the Map Collection of the Faculty of Science of the Charles University in Prague. In some cases it was not possible to find a map that would provide a suitable representation of the territories of Bohemia, Moravia and Silesia, e.g. for the period around 1920. In such cases we used two maps by different publishers from different years.

When selecting maps we took into account several factors, mainly the scale. We had to consider the level of detail of the maps so that the studied years were comparable and the level of detail in one year was not significantly different. However, it was not possible to find maps of the same scale for each year. With regard to the sources available and the demanding nature of the work, we selected maps of scales from 1:200 000 to $1: 500000$. Another factor we took into account was the type of map. Because earlier mapping was not done so often, we combined several types of maps. We used road maps as well as administrative and military maps.

Mere vectorisation of the materials could lead to inaccurate results. Moreover, varying scales can mean varying representation of road sinuosity, which would lead to completely different accessibility outputs for each year. Therefore, we used an existing digital geo-database with the road layer from 2001 (Arc ČR 500 by ArcDATAPraha, s.r.o.). To perform vectorisation, we always used an already completed digital network from a subsequent period. By analysing the differences and similarities, we created a network for the previous period. We used this method from the year 2001 and went either backward or forward in time.

Maps for each period were geo-referenced to the S-JTSK coordinate system. The number of ground control points differed according to the size of the represented territory. A ground control point was mainly placed over a junction (of a higher order, if possible). The type of transformation was chosen on the basis of subjective assessment of different areas on the map and of an evaluation of how the road network in the database corresponded to the network in the map. Cubic convolution was selected as the most suitable method for the calculation of the resulting pixel value. This method led to images of the highest quality.

For more recent periods and mainly for the cases of motorways and high-speed roads, the condition in the given year was compared to textual sources. We searched the dates of opening the given sections and adjusted the digital layer accordingly. We verified topological accuracy of data and corrected errors. Logically, there is no database for the model year 2020. We supplemented the ArcČR 500 database with plans of construction of particular sections of motorways and high-speed roads. The zoning plan already contains the stabilised route of the majority of planned constructions.

To calculate accessibility of road transport and to create the corresponding accessibility analyses we need a so-called accessibility model, described in detail e.g. in Hudeček (2008). This is a special dataset of digital vector data that represents the transport network and contains the junctions and edges, as well as adequately selected attributes - average speed and, therefore, time needed to reach the given distance. This enables the software to find e.g. the shortest route or to create isochrones by gradual load of the demanding nature of the route. The accessibility model for individual car transport offers 
the advantage of spatial universality. Once an accessibility model is created. it can serve for accessibility analyses of any point in the network. For each of the three selected years (1920, 1960 and 2020), we had to create a separate accessibility model. We used a fictitious passenger car as the means of transport. The following theoretical conditions were respected:

- The speed is constant on the given section of the type of the road.

- The car does not wait at traffic lights, when turning to the main road, during transit through a roundabout, etc.

- The car passes through grade-separated intersections as if they were level.

- The car does not violate traffic regulations valid at that time.

Stipulating the average speed plays one of the most important roles during the preparation of data for a network analysis. There are many factors that influence the average speed, e.g. class and width of the road, its sinuosity and longitudinal slope, traffic intensity, accident rate, time of the year, condition of the fleet, traffic regulations, condition of the road and repair works, and whether the road is inside or outside built-up areas (Hudeček, 2010). However, when performing a historical-geographical analysis for a period of one hundred years, we must take into account only the most important factors. After discussion, four factors were used for stipulating the average speed: road class, road width (number of traffic lanes), condition of the fleet and where the road is situated in relation to the system of settlement.

In each model, the road network was divided into three separate parts: Motorways and high-speed roads, other road sections going through built-up areas, and other road sections situated outside built-up areas. Taking into account many sources and information provided by eyewitnesses, as well as the traffic regulations of that time, road surface (dusty, gravel, concrete, bituminous) and fleet possibilities (e.g. the standard design speed of cars in 1937 was approximately $50 \mathrm{~km} / \mathrm{h}$ ), we stipulated the average speed for each model and road category (Tab. 1). Some sections were independently assigned speed on the basis of field research conducted by the author (town and city ring roads, through roads, etc.).

Tab. 1 Values of average speed in accessibility mode

Tab. 1. Vrijednosti prosječne brzine u modelima dostupnosti

\begin{tabular}{|c|c|c|c|c|c|c|}
\hline \multirow[b]{2}{*}{ Road type } & \multicolumn{2}{|c|}{$\begin{array}{c}\text { Average speed in } \\
1920 \\
\end{array}$} & \multicolumn{2}{|c|}{$\begin{array}{c}\text { Average speed in } \\
1960 \\
\end{array}$} & \multicolumn{2}{|c|}{$\begin{array}{c}\text { Average speed in } \\
2020 \\
\end{array}$} \\
\hline & $\begin{array}{l}\text { Built-up } \\
\text { area }\end{array}$ & $\begin{array}{c}\text { Outside } \\
\text { built-up } \\
\text { areas }\end{array}$ & $\begin{array}{l}\text { Built-up } \\
\text { area }\end{array}$ & $\begin{array}{c}\text { Outside } \\
\text { built-up } \\
\text { areas }\end{array}$ & $\begin{array}{l}\text { Built-up } \\
\text { area }\end{array}$ & $\begin{array}{c}\text { Outside } \\
\text { built-up } \\
\text { areas }\end{array}$ \\
\hline 1st class road & 15 & 40 & 30 & 60 & 30 & 70 \\
\hline Other roads (incl. 2nd class roads) & 10 & 20 & 20 & 30 & 25 & 50 \\
\hline Other roads (incl. 3rd class roads) & 10 & 20 & 20 & 30 & 20 & 40 \\
\hline 2nd class road (2 lanes) & & & & & 35 & 70 \\
\hline 1st class road (2 lanes) & & & 40 & 70 & 40 & 80 \\
\hline Motorway (3 lanes) & & & & & & 120 \\
\hline $\begin{array}{c}\text { Motorway (2 lanes), } \\
\text { high-speed road (3 lanes) }\end{array}$ & & & & & & 115 \\
\hline High-speed road (2 lanes) & & & & & & 110 \\
\hline
\end{tabular}

Source: Hudeček, 2008; Kufner, 2010 
The transformation of distance to time was done by assignment of average speed to the given road sections and by using a simple formula to calculate the temporal aspect:

$t=\frac{\frac{s}{1000}}{v}[$ hour $]$, where

$t \ldots$ the resulting temporal distance of individual edges needed to drive them through;

$s .$. the length of individual edges (road sections) separated by junctions (intersections);

$v \ldots$ the average speed of cars for individual road sections and individual years.

Note: The value of 1000 is due to the conversion to kilometres, distances in attribute tables are in metres.

The capital of Prague as a final destination was defined for the purpose of accessibility analyses as a circle with the radius of $5 \mathrm{~km}$. In each model, intersections of a thus defined centre with the road network were used as final destinations in the GIS analyses. We used ArcGIS, the Network Analyst extension, and the New Service Area function. The principle that lies behind the network analysis consists in finding the shortest (also from the temporal point of view) way to the final destination. The software checks all the ways from the centre to the closest junction and if the distance of a section (from the centre to the closest junction) is shorter than the maximum distance, software matches the end of the section with a code that contains information on the distance. The same procedure is applied to the following junctions. This cascade process of calculation then goes on in all directions until it reaches the determined destination. The resulting polygons created by the software - isochronic maps - are then visualised following the rules of thematic cartography.

\section{DIGITISATION OF MAPS AND AN ACCESSIBILITY MODEL - RAIL}

In this chapter we focus primarily on the methodological differences compared to road transport. The years used to calculate accessibility via rail transport were nearly the same as for road transport $(1920,1957,2020)$.

For these years, we used the timetables of Czechoslovak Railways (ČSD) and Czech

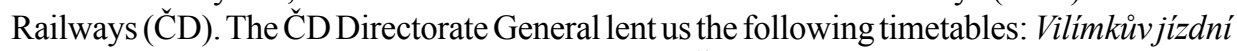
rád republiky československé 1918/19, jízdní rád ČSD 1957/58. Prospective data for 2020 are based on studies by the Passenger Transport Concept and Trade Policy Division of the Directorate General of the Czech Railways (Odbor koncepce a obchodu osobni dopravy generálního ředitelství $\check{C} D$ ). These are planned running times in corridors. Running times on other routes for 2020 draw from the 2008/09 timetable. For the accessibility analysis we selected all railway routes with regular traffic.

For the comparative historical-geographical analysis we chose fast trains as the suitable train type because this type has been present throughout the whole period of railway development and enables fast connection between important towns and cities 
in Czechia. On fast train routes we chose such a connection that covers the majority of stations with a connection to other lines. For these connection lines, passenger trains with suitable connections were chosen. Transfer time was counted as part of the overall travel time. If there was no transfer connection that would make the travel time shorter than one hour, such a section was excluded.

The analysis did not include special trains (Supercity, applies only for 2020) because these trains stop only at selected stations and their travel time was unknown during the time of research. Praha hl.n. and Praha Masarykovo nádražíwere selected as destination stations.

Using ArcGIS 9.2, we created passenger geo-databases for 1918, 1957 and 2020 and we imported classes of attributes of railway routes and railway stations from the digital vector geographical database Arc ČR 500. These data can be found in the S-JTSK coordinate system.

The dataset of railway routes from the Arc ČR 500 database from 2001 was edited so that it corresponded to the situation in the given year. The prospective situation in 2020 used map plots from a document provided by the Ministry of Transport of the Czech Republic. Minor rerouting was ignored because of the small scale of map outputs.

The section between each selected railway station was assigned time in minutes that consisted of the time needed to get across the section and the time of the train's waiting time in the preceding station. In practice, this meant finding a suitable connection from a given point to Prague using an electronic timetable (2009). For 1918 and 1957 we used printed timetables. Then we subtracted the time of travel between selected train stations. First, we processed the main railway routes with direct trains to Prague and subsequently supplemented them with connection trains. Topological errors like correct connection of lines at junctions, doubling of attributes, etc. were corrected. Similarly as in the case of the accessibility model for roads, we used ArcGIS 9.2, the Network Analysit extension, to create isochronic maps.

\section{ANALYSIS OF CHANGES IN ACCESSIBILITY FOR 1920 - 2020}

The distribution of time accessibility of Prague by road in 1918 (Fig. 1) on the Czech territory is even. The isochrones are not distinctly star-shaped. This is due to the nonexistence of motorways and high-speed roads, as well as to the general transport situation. In the period between the Wars, roads were not assigned the same hierarchy as today. Even though they were classified into state and district roads, there were minimum differences between them. Their surface was more or less the same and the design parameters of state roads were not significantly different from those of district roads (Lídl et al., 2009). In all the monitored periods and compared to all transport modes, time accessibility of Prague by road was most linked to distance accessibility.

For the whole Czech territory, there are no significant deviations from the relatively concentric zones of time accessibility of Prague. In 1918, the eastern part of Czechia, 


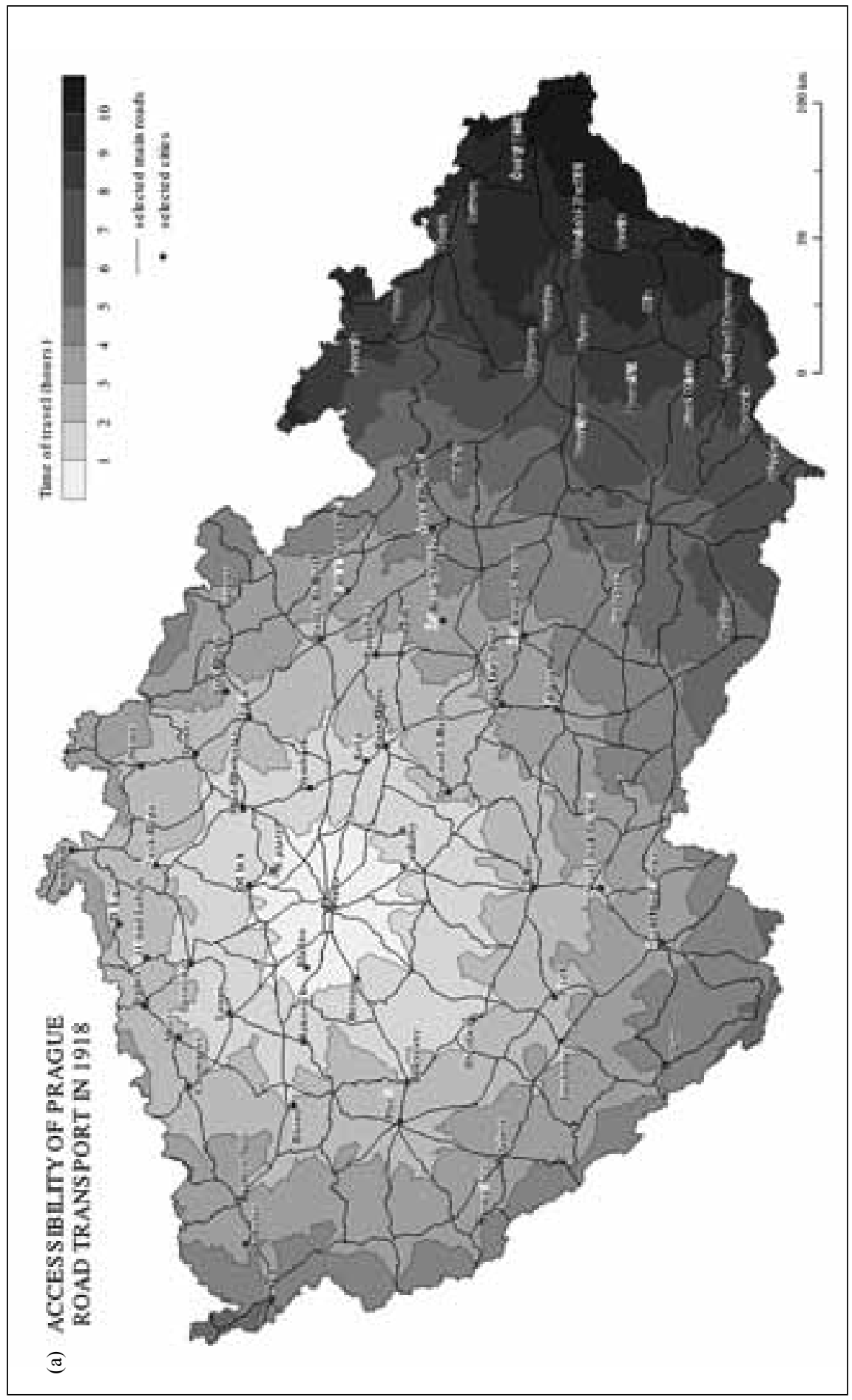

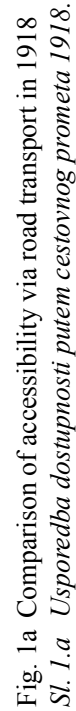




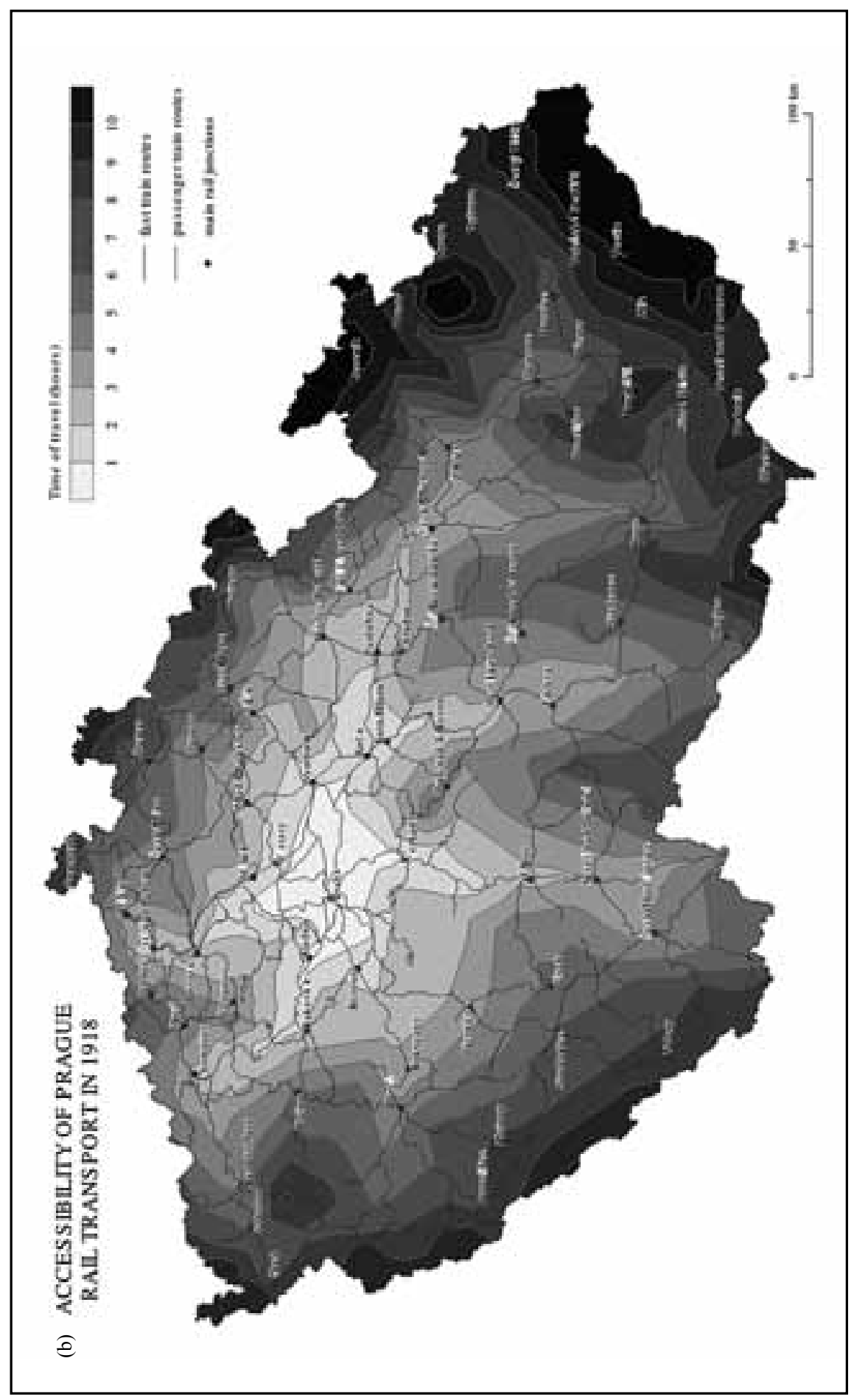

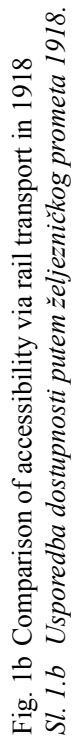


the Silesian border area, i.e. the territory farthest away from Prague, was theoretically accessible within 11 hours. The distance between the two biggest cities was 6 hours by car.

On the other hand, in the case of rail transport the routes and their condition correspond to the settlement patterns in Czechia in the 18th and 19th centuries. Compared to the relatively uniform accessibility of the territory by road, rail transport shows significant spatial unevenness (see also Marada, 2003). Moreover, due to the calculation algorithm, these considerable differences in the accessibility of Prague are further diminished because, in the case of rail transport, the calculations of accessibility logically pose problems for places with no rail routes. The research methodology, in order to be able to accurately determine the least accessible places, would have to be further refined in order to calculate more accurately the time of the journey to the nearest train station (e.g. by using public bus transport). Compared to road transport, we have to focus on the comparison of relevant places, i.e. places with rail routes present in a particular period.

The main development axis of the Czech Republic, represented by the east - west rail corridor, going through towns and cities like Děčín (north-west), Chomutov (west), Prague, Česká Třebová, Olomouc and Ostrava (east), made it possible to go through the Czech territory in approximately 11 hours. From Prague it took 3 hours to the west and 8 hours to the east (to the city of Ostrava). This is considerably less (by up to one third) than in the case of road transport (especially to the east of Prague). A similar situation arises for the southward corridor, from Prague to České Budějovice. The direction and the connecting line of the most important Czech cities, Prague and Brno, do not follow the optimum direct connection. It is rather interesting that, even in 1918, the connection between these two cities took 6 hours theoretically, i.e. the same time as in the case of road transport.

In the case of time accessibility in 1960 (or 1957, Fig. 2) there was an improvement in accessibility for road transport, especially along all 1st class roads (the majority of which was reinforced at that time). It took up to 3 hours to reach the majority of places in Bohemia from Prague. However, because of the non-existence of motorways and high-speed roads, the accessibility of Prague was quite even, especially due a relatively homogeneous density of 1 st class roads. The infrastructure development state policy at that time had been considering the construction of motorways (mainly because of the demand for road transport in general, the increasing number of passenger cars, and the economic development - still much slower than in Western Europe due the Communist regime. Nevertheless, the construction started only in the 1970s. Prague was accessible more quickly, from Ostrava (eastern border) in 6 hours and from Brno in 4 hours.

There was only minimum change in the placement of rail routes. Intensifying and capacity building of rail transport led to a global improvement in the accessibility of Prague compared to the previous period (though a relatively moderate one). On the other hand, there was the phenomenon of consolidation of the regional disparities described above. The distance from Ostrava to Prague shortened by one hour, from 8 to 7 hours. The distance from Brno to Prague shortened from 6 to 5 hours.

When comparing accessibility with the use of both transport modes it is clear that, at that time, the time accessibility of road transport was better than that of rail transport, 
even though there had been no investment into motorways and high-speed roads. In 1960 this was true not only for places with no rail routes leading to Prague but also for big settlement centres with railway infrastructure.

In 2020, thanks to a radial system of motorways and high-speed roads around Prague (Fig. 3), it will be possible to get by car to almost anywhere in Czechia within three hours. This is true only for so-called theoretical accessibility and only in case the planned network of motorways and high-speed roads is completed. An increasing number of studies (e.g. Kraft and Vančura, 2008) note that there is a considerable worsening of transport accessibility by roads due to an unprecedented densification of road traffic and an increase in the use of railways. However, it is neither the aim nor in the scope of our research to predict the increase in this factor. The accessibility model uses proportionate data when considering the average speed allowed on motorways and, therefore, the resulting values are relatively in correspondence with the reality.

Time accessibility of the two biggest centres by road should not go beyond 1 hour and 40 minutes. From Ostrava to Prague the journey should shorten by approximately 3 hours compared to the previous period. Prague should be accessible from the whole territory of Bohemia in 1 hour and 30 minutes, and in up to 2 hours from the border regions.

The current modernisation of rail corridors (which will probably not be completed by 2020) is designed for the maximum speed of $160 \mathrm{~km} / \mathrm{h}$. This means that rail transport will be able to compete with road transport once again. However, we need to note the following: The model does not take into account the highest-standard trains. The use of such trains can lead to a further shortening of the time because these trains only make stops in the biggest Czech settlement centres. Thus, the time distance from Ostrava to Prague will not be 3 hours and 15 minutes (as in Fig. 3) but 3 hours. However, shortening the distance from Brno to Prague to less than 2 hours will probably not be possible even in 2020 .

The comparison of the two transport modes in this period shows that there is a renaissance of rail transport in Czechia in terms of the accessibility of Prague. The connection of Prague with important settlement centres by rail can compete, in terms of time accessibility, with road transport. However, the long-term invariability of rail corridors in Czechia leads to a conservation of transport directions and routes, creating a historical predetermination of this mode. There will remain territories (mostly border areas but also places of low economic potential, as seen in the 18th and 19th centuries) that will not be connected by rail. This confirms, for all the studied periods, the selectivity of various transport modes mentioned by geographers (e.g. Marada and Hudeček, 2006). A possible construction of high-speed rail routes could lead to a change; however, no such construction is planned in the Czech Republic by 2020.

\section{DISCUSSION}

All accessibility analyses were made in relation to Prague. Using accessibility models for each monitored period, we analysed time accessibility from all areas in Czechia to the capital. Taking into account the nature of the research, we can interpret the results the other way round, i.e. as the accessibility of different areas in Czechia from Prague. 


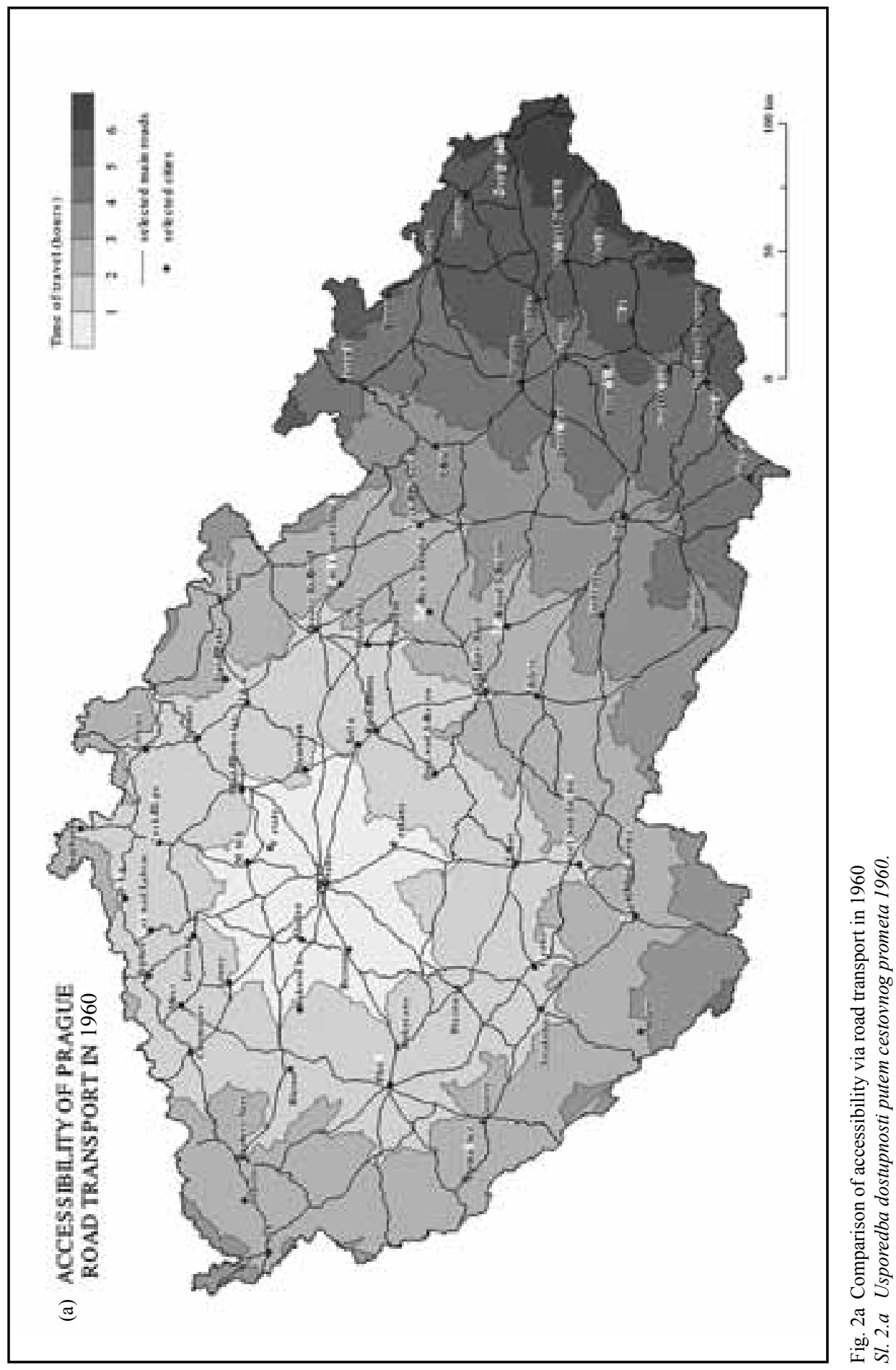




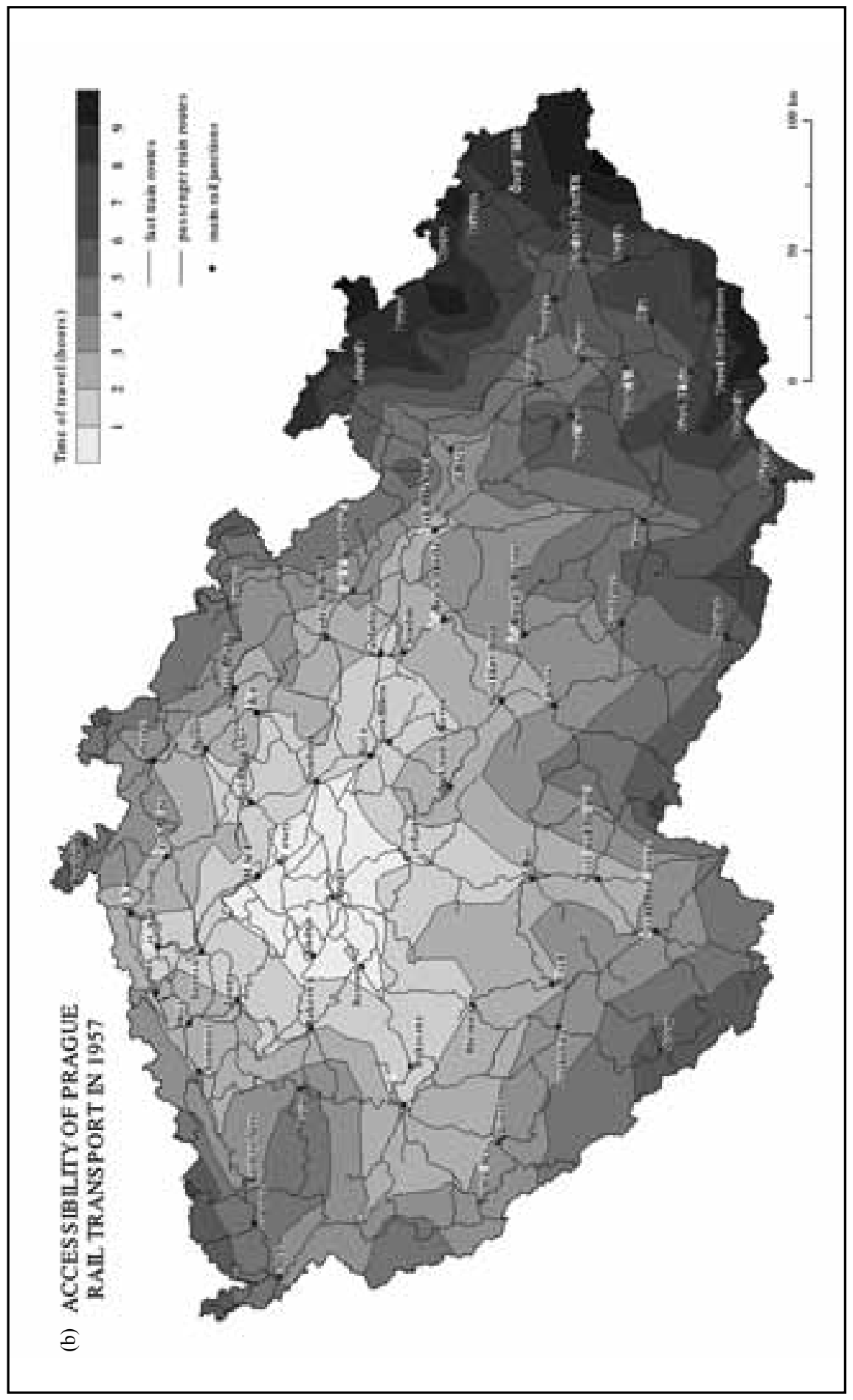

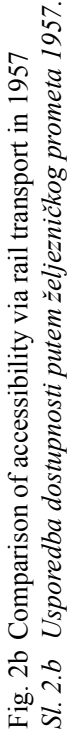




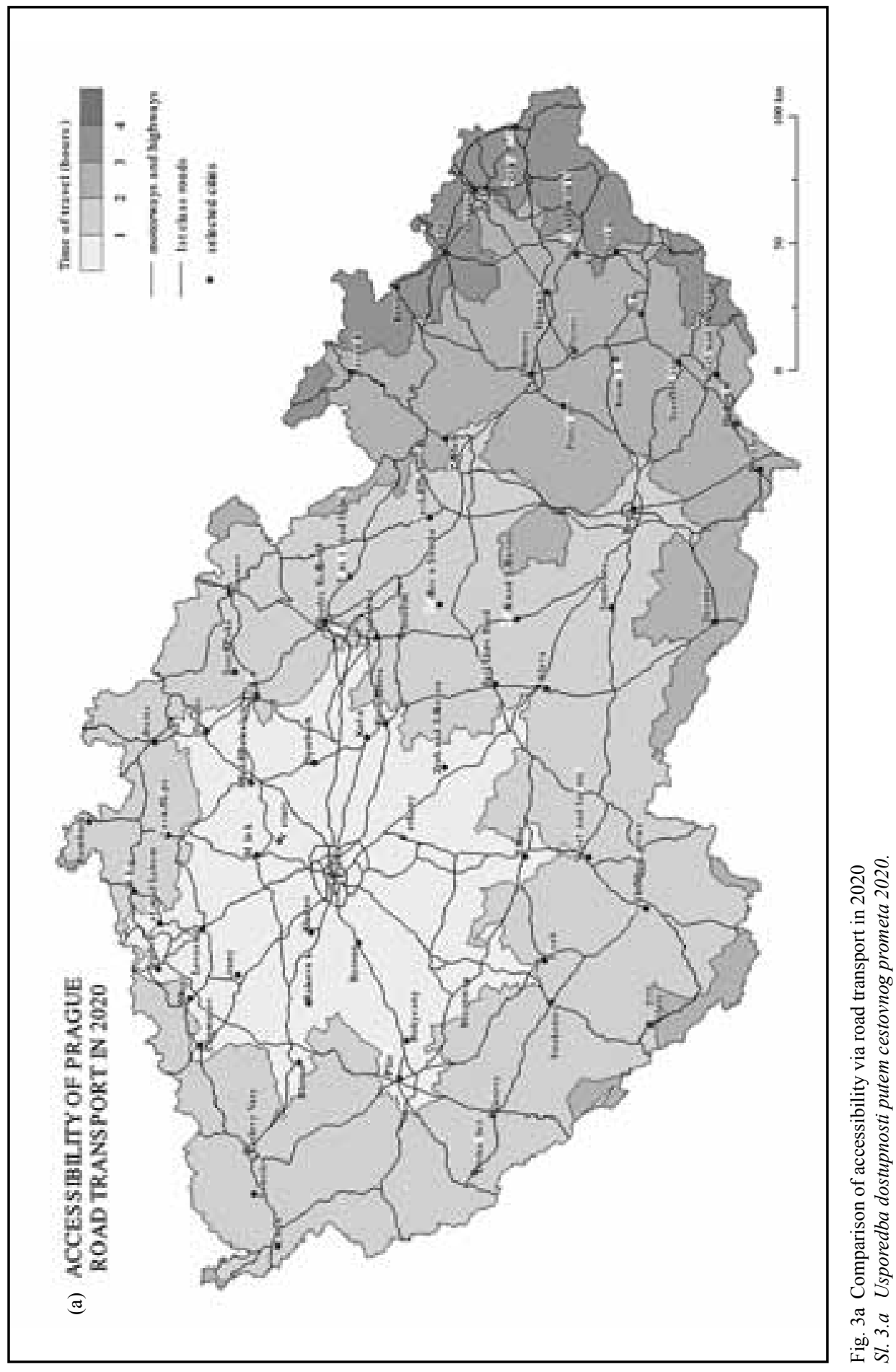




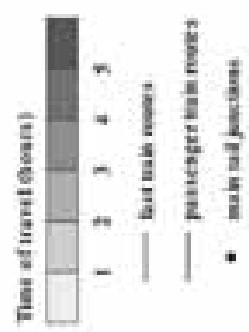


The methodology of creation of accessibility models has to be viewed critically, similarly to the results of the analysis. While in the case of monitoring time accessibility by rail we can base our analyses on the timetable, in the case of road transport we have to estimate the average speed on the roads and, moreover, the speed has to be classified according to various factors that do not take into consideration local and individual disparities.

Such facts influence the analysis. For example, we cannot estimate what the 2020 timetable will look like. Therefore, we determined the accessibility on the basis of existing connections by modifying their parameters according to modernised routes. In the case of major directions and routes, we consulted the representatives of state transport authorities. On the other hand, the factor of average speed on roads is more or less influenced by the density of traffic, which may significantly reduce the accuracy of the estimate for the future.

The comparison of the degree of ,,benefit" resulting from each transport mode is looked upon merely in terms of time accessibility, a rather narrow point of view. It is clear that an important role is also to be played by the level of comfort, as well as the price, reliability and safety of the journey (Zelený, 2004). Nevertheless, these methodological constraints do not render the conclusions irrelevant and the conclusions can serve for further research.

\section{CONCLUSION}

The parts of the historical geographical study on accessibility in Czechia described above, namely the accessibility of Prague by roads and rail for the $1918-2020$ period, must be viewed as having a certain degree of uniqueness. Research on accessibility in such a long historical period (presented here in the form of three referential periods due to the scope of this paper) cannot simply be compared to other geographical and geoinformatics studies. There is lack of comparable studies as this is the first time in which map input has been digitised and used as a basis for the creation of accessibility models in the Czech Republic.

For Czech geography, this represents a basis for further research on the regional development of the relation between shortening of distances and its influence on the system of settlement, housing and, possibly, also suburbanisation.

We used isochronic maps, currently the most suitable method of thematic cartography, to illustrate the results. All historical analyses faced the problem of low availability of old maps and their subsequent digitisation. One of the important outputs of the research includes the electronic versions of transport networks in Czechia.

The research will now focus on supplementing the current results with an analysis of change in accessibility from other centres in Czechia and with monitoring of accessibility with the use of air and water transport. To ensure better visualisation of changes in accessibility, the authors have developed a methodology of automatic creation of cartographic radial distortion, i.e. a more advanced and illustrative way of accessibility visualisation. 


\section{REFERENCES}

Blahník, P., 2008: Historicko-geografická analýza dostupnosti Prahy železniční dopravou v obdobi 1918-2020 pomoci GIS. PrF UK, Praha, 49.

Giuliano, G., 1995: Land Use Impacts of Transportation Investments: Highways and Transit. In: The Geography of Urban Transportation (Hanson, S.), The Guilford Press, London, 305-341.

Grégr, P., 1994: Dopravní poloha a role středisek centrální části České republiky. Geografie - Sborník ČGS 99 (3), 178-188.

Golias, J. C., 2002: Analysis of traffic corridor impacts from the introduction of a new metro system. Journal of Transport Geography 10 (1), 91-97.

Gutiérrez, J., Gonzáles, R., Gómez, G., 1996: The European high-speed train network. Journal of Transport Geography 4 (4), 227-238.

Hudeček, T., 2008: Model časové dostupnosti individuální automobilové dopravy. Geografie-Sborník ČGS 113 (2), 140-153.

Hudeček, T., 2010: Dostupnost v Česku v obdobi 1991-2001: vztah k dojižd'ce do zaměstnáni a do škol. ČGS, Praha, 146.

Hůrský, J., 1971: Vliv dopravy na diferenciaci ČS. regionálních center v polovině 19. století. Geografie-sborník $\check{C} G S 76$ (4), 265-270.

Hůrský, J., 1978: Metody oblastního členění podle dopravního spádu. Rozpravy Československé akademie věd 88 (6). 1-96.

Kraft, S., 2008: "Time accessibility”- přiklad deformace prostoru generované dopravou. Miscellanea Geographica $14,77-84$.

Kraft, S., Vančura, M., 2008: Prostorová analýza konkurenceschopnosti železnični dopravy v České republice z hlediska časové efektivity. In: Recenzovaný sborník příspěvků ze semináře "Telč 2008”, Brno, 108 - 122.

Kubeš, J., Slezaková, A. , 2000: Vybavenost venkovských sídel osobni hromadnou dopravou pro rok 1988/89. In: Kubeš, J. (ed.): Problémy stabilizace venkovského osídlení ČR. JČU v ČB, České Budějovice, 123-125.

Kufner, J., 2010: Historicko-geografická analýza dostupnosti Prahy silnični dopravou v období 1918-2020 pomoci GIS. PrF UK, Praha, 55.

Li, S., Shum, Y., 2001: Impacts of the National Trunk Highway System on Accessibility in China. Journal of Transport Geography 9 (1), 39-48.

Lidl, V. ... et al., 2009: Silnice a dálnice v České republice, Agentura Lucie, Praha, 380 s.

Nový, V. 1904: Isochronická mapa Čech - s úvodem o isochronách vůbec. Zeměpisná knihovna, Praha, 31.

Marada, M., 2003: Dopravní hierarchie středisek v Česku: Vztah k organizaci osídlení. Univerzita Karlova, Praha, 116.

Marada, M., Hudeček, T., 2006: Accessibility Of Peripheral Regions: A Case of Czechia. Europa XXI 15, 43-51.

Mirvald, S., 1998: Význam dopravy a předmět výzkumu geografie. In: Holeček, M. (ed.): Současný stav a perspektivy dopraví geografie - sborník ze semináře. ČGS, Brno, 25-29.

Nutley, S., 2003: Indicators of transport and accessibility problems in rural Australia. Journal of Transport Geography 11 (1), 55-71.

Peňáz, T., 2005: Zpřesnění liniového dopravniho modelu sitě pozemnich komunikací pro účely analýzy dopravní dostupnosti. In: Sborník referátů z konference "GIS Ostrava 2005”, Ostrava, 136.

Rietveld, P., Bruinsma, F., 1998: Is transport Infrastructure Effective?, Springler, Heidelberg, 375.

Rölc, R., 2004: Hierarchie osidlení a doprani systémy: specifika měritkové diferenciace na přikladě České republiky, Univerzita Karlova, Praha, 166. 
Sić, M., 2008: Utjecaj autoceste Zagreb - Split na regionalni razvoj Like, Hrvatski geografski glasnik 70 (2), 87-100Spence, N., Linneker, B., 1994: Evolution of the motorway network and changing levels of accessibility in Great Britain. Journal of Transport Geography 2 (2), 247-264.

Spiekermann, K., Wegener, M., 1996: Trans-European Networks and Unequal Accessibility in Europe. EUREG (4), 35-42.

Zelený, L., 2004: Rozvoj dopravy ve světě. VŠE, Praha, 128.

\section{Acknowledgements}

The paper was written with financial support of the Grant Agency of the Czech Republic (GAČR). The paper is part of the GAČR grant "Analysis of accessibility patterns in Czechia from 1921 to 2020 ".

Received (Primljeno): 2010 - 12 - 31

Accepted (Prihvaćeno): $2011-09-22$

RNDr. Tommáš Hudeček, PhD

Department of Applied

Geoinformatics and Cartography

Faculty of Science

Charles University in Prague

Albertov 6

12843 Prague 2

hudecek@dr.com 